\title{
Cevizde (cv. Chandler) Kompoze Mikrobiyal Gübre Kullanımının Verim ve Kalite Parametreleri Üzerine Et- kilerinin Araştırılması
}

\author{
Investigation of the Effects of a Compound Microbial Fertilizer Use on Yield and Quality \\ Parameters in Walnuts (cv. Chandler)
}

\section{Nihal ACARSOY BILGIIN*}

Ege Üniversitesi Ziraat Fakültesi

Bahçe Bitkileri Bölümü Bornova / İzmir

nihalacarsoy@yahoo.com

(iD) 0000-0002-5018-6347

\section{Adalet MISIRLI}

Ege Üniversitesi Ziraat Fakültesi

Bahçe Bitkileri Bölümü Bornova / İzmir

(iD) 0000-0002-6128-9974

\section{Fatih ŞEN}

Ege Üniversitesi Ziraat Fakültesi

Bahçe Bitkileri Bölümü Bornova / İzmir

(iD) 0000-0001-7286-2863

*Sorumlu yazar

Gönderilme Tarihi : 2 Mayıs 2020

Kabul Tarihi : 19 Mayıs 2020

\section{ÖZET}

Günümüzde, çevre dostu etkileri sebebiyle, tarım uygulamalarında faydalı mikroorganizmalar etkin şekilde kullanılmaktadır. $\mathrm{Bu}$ mikroorganizmalar, bitki besin elementi içeriğini arttırması sayesinde meyve kalite özellikleri ve verim üzerine olumlu etki sağlamaktadır. $\mathrm{Bu}$ bağlamda, 3 farklı dönemde, yapraktan mikrobiyal gübre (EM.A ve EM.5) uygulamalarının 'Chandler' ceviz çeşidinde, verim ve bazı meyve özellikleri üzerine etkilerinin belirlenmesi amaçlanmıştır. Demirci/Manisa'da 2018 ve 2019 yılları arasında yürütülen çalışmada, iki yılın ortalaması dikkate alındığında, meyve ağırlığı (12.62 g), eni $(33.60 \mathrm{~mm})$ ve yükseklik $(41.13 \mathrm{~mm})$ bakımından EM.A uygulaması ilk sırada yer almıştır. Her iki yararlı mikrobiyal gübre uygulaması ile $\mathrm{a}^{*}$ değerinde artış, $\mathrm{C}^{*}$ değerinde azalış gözlenmiştir. Genel olarak, meyvede, linoleik asit (\%62.74 ile EM.5) düzeyi yüksek olurken bunu sırasıly linoleinik (\%16.21 ile kontrol) ve oleik asit (\%13.22 ile EM.A) izlemiştir. Ağaç başına en yüksek verim EM.5 uygulamasında ( $2.52 \mathrm{~kg} /$ ağaç), en düşük verim ise uygulama yapılmayan ağaçlarda $(0.78 \mathrm{~kg} / \mathrm{ağaç})$ saptanmıştır.

Anahtar kelime: Juglans regia L., mikrobiyal gübre, meyve özelliği, yağ asidi, verim 
Abstract: Nowadays, beneficial microorganisms are used effectively in agricultural applications due to its environmentally-friendly effects. These microorganisms, used in different areas, provide a positive effect on quality properties and yield by increasing the amount of plant nutrients. In this context, it was aimed to determine the effects of foliar microbial fertilizer applications (EM.A and EM.5) on yield and some fruit characteristics for 'Chandler' walnut variety in 3 different periods. The study was carried out in Demirci/Manisa district between 2018 and 2019, EM.A application ranked the first in terms of fruit weight $(12.62 \mathrm{~g})$, width $(33.60 \mathrm{~mm})$ and diameter $(41.13 \mathrm{~mm})$. In both beneficial microbial fertilizer applications, a * value increased and $\mathrm{C} *$ value decreased. In general, the level of linoleic acid (EM.5 with $62.74 \%$ ) was high in fruit, was followed by linoleinic (control with 16.21\%) and oleic acid (EM.A with $13.22 \%$ ), respectively. The highest yield was determined in EM.5 application and the lowest was found in untreated trees $(0.78 \mathrm{~kg} /$ tree).

Keywords: Juglans regia L., microbial fertilizer, fruit characteristics, fatty acid, yield

\section{Giriş}

Artan dünya nüfusunun gida ihtiyacinı karşılayabilmek amacıyla yoğun ve bilinçsiz girdi kullanımı insan sağlığını olumsuz etkilemekte ve ekosistem dengesi üzerine önemli zararlara neden olmaktadır. Zira, verimlilik, besin elementlerinin toprakta dağılımı, formu ve yarayışlılığına etki eden faktörlere bağlı olarak, bitki tarafından yeterli miktarda alınımına bağlıdır (Zaman vd. 2014). Bu bağlamda, sürdürülebilirlik açısından çevre dostu tarım uygulamaları geniş çapta kullanılmaktadır. Bu bilincin ön plana çıktığı günümüzde, kimyasal gübreye karşı çözüm alternatifleri arasında yer alan yeşil gübreler ve mikrobiyal kökenli gübrelerin kullanımı önem taşımaktadır (Welbaum vd. 2004; Dede 2013; Mertoğlu vd. 2018).

Yararlı mikroorganizmalar insan ve çevre sağlığı, gıda işleme ve kalitesi, genetik mühendisliği ile biyoteknoloji gibi alanlarda kullanılmaktadır (Higa ve Parr 1994). Bitki gelişimini iyileştirici etkiye sahip olan bu mikroorganizmaların fizyolojik etkileri 20. yy'ın başından itibaren dikkat çekici bulunmuştur (Parewa vd. 2014; Ruzzi ve Aroca 2015; Bona vd. 2016). Bu mikroorganizmaların ürettikleri aktif maddeler ile meyve türlerinde vejetatif gelişme, meyve özellikleri, besin elementi içeriği, hastalıkların kontrolü ve verim üzerine olumlu etki yaptığ1 belirlenmiştir (Ertürk vd. 2012; Karlıdağ vd. 2013; İpek vd. 2014; Güneş vd. 2015; Thakur vd. 2015; Rostamikia vd. 2016; Shakeel ve Hassan 2018). Kisa sürede sonuca ulaşılan ve ürün miktarı üzerinde direkt etkili olan bu uygulamalar, toprak, yaprak ve çiçeklere teksel ya da kombine şeklinde gerçekleştirilmektedir (Eşitken vd. 2010; Atılgan vd. 2019). Bu grubun içinde fotosentetik ve laktik asit bakterileri, mayalar, funguslar ve etkili enzimler yer almaktadir.

Mikroorganizmaların etkileri konusunda birçok meyve türünde verim ve kalite üzerine çalışma yapılmış olmasına rağmen, cevizde biyolojik mücadele, fidan gelişim ve verim ile kalite etkilerini kapsayan sınırlı sayıda çalışma bulunmaktadır (Liu vd. 2014; Shakeel ve Hassan 2018). Diğger yandan, tüketim talebinin her geçen gün arttığı günümüz şartlarında, besin değeri 
ve özellikle farklı yağ asitleri kompozisyonu içermesi nedeniyle fonksiyonel gıdalardan olan ceviz, beslenme programlarında çok önemli bir yere sahiptir (Şen 2017). Bu türde, özellikle 'Chandler' çeşidi ile yeni bahçeler tesis edilmiş, üretim alanları genişlemiştir. Söz konusu ceviz çeşidinde planlanan bu çalışmada, mikrobiyal gübrelerin kullanımı ile bazı kalite parametreleri ve verime olan etkilerinin belirlenmesi amaçlanmıştır.

\section{Materyal ve Yöntem}

Manisa ili Demirci ilçesinde (3902'39'N 2835'56”'E, yükseklik 740 m), 2018 ve 2019 yıllarında yürütülen bu çalışmada, 2012 yılında tesis edilen üretici bahçesindeki 'Chandler' ceviz çeşidi bitkisel materyal olarak kullanılmıștır. ABD’de Pedro X 56-244 kombinasyonunun bir melezi olarak elde edilen bu çeşit, orta kuvvette büyüyerek yarı dik taç oluşturur. Soğuklama ihtiyacı 700 saat olup, yapraklanması ve çiçeklenmesi geç dönemde olmaktadır. Yan dallarda meyve verimi yüksektir (\%80-90). Kendine verimli olan bu çeşidin meyveleri iri, oval, kabuğu pürüzsüz, zayıf ve kırılgandır. Meyve iç ağırlığı $6.5 \mathrm{~g}$, iç oranı ise \%49'dur. Meyveleri orta mevsimde olgunlaşır (Özçağıran vd. 2014). Denemenin yürütüldüğü bahçede sulama damla sulama yöntemi ile yapılmış olup, kültürel uygulamalar düzenli olarak gerçekleştirilmiştir. Ayrıca maksimum ve minimum sicaklık değerleri Çizelge 1'de verilmiştir.
Agriton firmasına ait EM.A ve EM.5 mikrobiyal gübreler ceviz ağaçlarına erkek çiçekler açmadan önce, erkek çiçekler açtıktan sonra ve meyveler fındık büyüklügünne ulaştığında olmak üzere, pülverizatör ile yapraktan üç farklı dönemde püskürtülmüştür. Denemede, kontrol grubu ağaçlarına ise su püskürtülmüştür. Mikrobiyal gübrelere ait içerik ve uygulama dozu bilgileri Çizelge 2'de yer almaktadır.

Hasat edilen meyveler yeşil kabuklarından ayrılarak gölgede kurutulmuş ve Ege Üniversitesi Ziraat Fakültesi Bahçe Bitkileri Bölümü'nde analiz edilmiştir. Ortalama meyve ve iç ağırlığı hassas terazide $(0.01 \mathrm{~g})$ tartılmışve bu değerlerden yararlanarak iç randımanı (\%) hesaplanmıştır. Dijital kumpas ile $(0.01 \mathrm{~mm})$ meyve eni, boyu, yüksekliği ve kabuk kalınlığı (mm) ölçülmüştür (Şen 1980). Meyve iç rengi Minolta renk ölçer (CR-400, MinoltaCo, Japonya) ile CIE L*, $\mathrm{a}^{*}, \mathrm{~b}^{*}$ ölçülerek bu değerlerden kroma $\left(\mathrm{C}^{*}=\right.$ $\left.\left[\mathrm{a} * 2+\mathrm{b}^{* 2}\right]^{1 / 2}\right)$ ve hue açısı $\left(\mathrm{h}^{\circ}=\tan ^{-1}[\mathrm{~b} / \mathrm{a} *]\right)$ değeri hesaplanmıştır (McGuire 1992). Hasat zamanında, her ağaçta toplam verim (kg) kaydedilmiş ve tekerrürlerin aritmetik ortalaması alınarak, bitki başına verim hesaplanmıştır. Soxholet metodu ile ekstrakte edilen yağdan, yağ oranı (\%) belirlenmiştir. Örnek kartuşlarına 10 g öğütülmüş ceviz konularak, çözücü hekzan ile yağ ektrakte edilmiştir. Sonrasında ortamdan çözücü uzaklaştırılarak, ham yağ elde edilmiştir. Ham yağ miktarından formülle yağ miktarı hesaplanmıştır [Yağ miktarı $(\%)=($ Ham yağ $(\mathrm{g}) /$

Çizelge 1. Aylık ortalama sıcaklık değerleri $\left({ }^{\circ} \mathrm{C}\right)$

\begin{tabular}{|c|c|c|c|c|c|c|c|c|c|c|c|c|c|}
\hline & & Ocak & Şubat & Mart & Nisan & Mayıs & Haziran & Temmuz & Ăgustos & Eylül & Ekim & Kasım & Aralık \\
\hline $\mathbf{2 0 1 8}$ & Max & 9.3 & 11.6 & 15.0 & 23.1 & 24.7 & 27.5 & 30.3 & 31.4 & 27.2 & 22.1 & 16.1 & 8.3 \\
\hline & Min & 2.9 & 5.2 & 6.9 & 12.4 & 14.3 & 16.7 & 19.2 & 20.1 & 16.8 & 12.1 & 8.6 & 2.0 \\
\hline $\mathbf{2 0 1 9}$ & Max & 6.7 & 11.0 & 14.7 & 16.5 & 23.2 & 27.6 & 29.8 & 32.1 & 28.1 & 24.2 & 18.8 & 10.7 \\
\hline
\end{tabular}


Çizelge 2. Mikrobiyal gübre ve içerikleri.

\begin{tabular}{|l|l|l|}
\hline Mikrobiyal gübre & İçeriği & Uygulama dozu \\
\hline EM.5 & $\begin{array}{l}\text { Laktik asit bakterisi (Lactobacillus delbrueckii, Lactobacillus } \\
\text { plantarum, Lactobacillus rhamnous, Lactobacillus casei), } \\
\text { Mayalar (Saccharomyces cerevisiae) } \\
\text { Fotosentez bakterileri (Rhodopseudomonas palustris) }\end{array}$ & $2 \mathrm{cc} / \mathrm{lt}$ \\
\hline EM.A & $\begin{array}{l}\text { Laktik asit bakterileri (Lactobacillus fermentum, Lactobacillus } \\
\text { plantarum, Lactobacillus rhamnous, Lactobacillus casei, } \\
\text { Lactobacillus delbrueckii), } \\
\text { Mayalar (Saccharomyces cerevisiae) } \\
\text { Fotosentez bakterileri (Rhodopseudomonas palustris) } \\
\text { Diğerleri }\end{array}$ & $2 \mathrm{cc} / \mathrm{lt}$ \\
\hline
\end{tabular}

Örnek miktarı) x 100]. Meyvedeki yağ asitleri oranları, soğuk ekstraksiyon ile elde edilen ham yağ örneklerinin esterleştirilmesi ile elde edilen fazın gaz kromotogafisinde okutulması ve çıkan grafiğin yorumlanması ile (\%) hesaplanmıştır. Yağ asidi ve verim değerleri denemenin ilk yılında hesaplanmıştır.

Deneme tesadüf bloklarında bölünmüş parseller deneme desenine göre 3 tekerrürlü ve her tekerrürde 3 ağaç olacak şekilde planlanmıştır. Her tekerrürde 10 meyve örneği değerlendirilmiştir. Elde edilen verilere SPSS 20 istatistik programı kullanılarak, varyans analizi yapılmış ve Duncan testi $(\mathrm{P} \leq 0.05)$ ile ortalamalar arasındaki farklılıklar belirlenmiştir.

\section{Bulgular ve Tartışma}

'Chandler' ceviz çeşidine ait incelenen meyve özelliklerine ilişkin bulgular Çizelge 3'de verilmiştir. İki yılın ortalamasına göre meyve ağırlığı, eni ve yüksekliği uygulamalara göre istatistiksel düzeyde farklılık göstermiştir. Buna göre, meyve ağırlığı bakımından en düşük değer kontrol grubunda ölçülürken (11.53 g), uygulamaların bu özellik bakımından olumlu etkiler gösterdiği ve meyve ağırlığının EM.A ve EM.5 uygulamaları sonucu sırası ile $12.62 \mathrm{~g}$ ve $12.41 \mathrm{~g}$ düzeylerine çıktığı tespit edilmiştir. Benzer durum meyve eni ve yüksekliğinde de gözlenmiştir. Buna göre, meyve eni ve yüksekliği bakımından kontrol (32.68 ve $39.75 \mathrm{~mm}$ ) ve EM.A (33.60 ve $41.13 \mathrm{~mm})$ uygulamaları ile sınır değerleri elde edilmiştir. Diğer yandan, meyve ağırlığında ilk yılda, kabuk kalınlığ 1 ve meyve yüksekliğinde ise ikinci yılda istatistiksel düzeyde farklılık saptanmıştır. Meyve ağırlığ1 bakımından, 2018 yılında, en yüksek değer $12.85 \mathrm{~g}$ ile EM.A uygulamasında saptanırken bunu 12.47 g ile EM.5 ve 11.98 g ile kontrol uygulaması izlemiştir. Denemenin ikinci yılında, uygulamalara bağlı değişim aralığının kabuk kalınlığında 1.53 (EM.A, EM.5) - 1.83 mm (kontrol) ve meyve yüksekliğinde ise 39.75 (kontrol) - $41.13 \mathrm{~mm}$ (EM.A) olduğu tespit edilmiştir. Sonuç olarak, her iki mikrobiyal gübre uygulaması ile kabuk kalınlığı azalırken, meyve ağırlığı ve yüksekliğinde artış kaydedilmiştir. Zira bu değerler tüketici kalite kriterleri arasında ilk siralarda yer almakta ve mikrobiyal gübrenin 
önemini vurgulamaktadır.

Cevizde, besin maddesini kullanılabilir forma dönüşmesini sağlayan yararlı bakterilerin (Pseudomonas fluorescens), meyve boyutları üzerinde olumlu etki gösterdiği ifade edilmektedir (Acarsoy Bilgin vd. 2018). Diğer yandan, söz konusu ticari mikrobiyal gübre uygulamas1 (EM.5 + EM.FPE) ile zeytinde yürütülen bir diğer çalışmada, kontrole kıyasla meyve ve çekirdek ağırlığı, meyve eni ve boyu bakımından istatistiksel artış kaydedildiği bildirilmektedir (Acarsoy Bilgin 2019). Meyve türlerinde, verim, kalite ve bitki gelişimini teşvik edici mikrobiyal preparatların kullanıldığı çok sayıda çalışma bulunmasına rağmen, cevizde ise bu durum fidan gelişimi ve fungal hastalıklara karşı etkinlik çalışmaları üzerinde yoğunlaşmıştır (Liu vd. 2014; Shakeel ve Hassan 2018).

Ülkemiz topraklarında görülen bitki besin maddesieksikliğinin(Solmaz2014), önlenmesine yönelik özellikle organik ve mikrobiyal kökenli gübrelerin kullanılmasının yaygınlaşması gerektiği vurgulanmaktadır (Mordoğan vd. 2013). Diğger yandan, meyve kalite özellikleri ve verimin ekolojik koşullara göre değişkenlik gösterdiği bilinmektedir (Forde 1975; Ramos 1998; Mertoğlu ve Evrenosoğlu 2017). Nitekim, rakımı yüksek olan Demirci ekolojisinde yaz sıcaklıklarının düşük olması (Çizelge 1) meyve iç ağırlı̆̆ını tam dolduramaması ve uygulama yapılmayan ağaçlarda meyve ağırlı̆̆ının nispeten az olmasına yol açmıştır.

Uygulamalara göre ölçülen meyve renk parametreleri Çizelge 4' de gösterilmiştir. İki yılın ortalamasına göre yatay eksende (+) kırmızıyı, (-) yeşili ifade eden $a^{*}$ değeri ve parlaklığımatlı̆̆1 ifade eden ve $\mathrm{C}^{*}$ değerleri istatistiksel bakımdan önem taşımamaktadır. EM.A (8.34) ve EM.5 (8.16) uygulaması ile 'Chandler' çeşidinin $a^{*}$ renk değeri kontrol (7.11) uygulamasına göre daha yüksek bulunmuştur. Buna karş1lık, C* değerinde EM.A (73.84) ve EM.5 (74.35) uygulamalarının kontrole (76.42) kıyasla azalması doygunluk değerinin azalmasına işaret etmektedir.

Denemenin ikinci yılında $\mathrm{L}^{*}, \mathrm{a}^{*}$ ve $\mathrm{C}^{*}$ değerlerinde uygulamalara göre istatistiksel farklılık ortaya çıkmıştır. Meyvede, açık koyuluğu ifade eden L* değerleri, 48.78 (EM.5) - 55.81 (kontrol) sınırlarında değişim göstermiş

Çizelge 3. Uygulamaların meyve özelliklerine etkisi

\begin{tabular}{|c|c|c|c|c|c|c|c|c|}
\hline & & $\begin{array}{l}\text { Meyve } \\
\text { ağırlığ } 1 \\
\text { (g) }\end{array}$ & $\begin{array}{c}\dot{\mathrm{I} c ̧} \\
\text { ağ|rlı̆̆1 } \\
(\mathrm{g})\end{array}$ & $\begin{array}{c}\text { İç } \\
\text { randımanı } \\
(\%)\end{array}$ & $\begin{array}{l}\text { Kabuk } \\
\text { kalınlığ } 1 \\
(\mathrm{~mm})\end{array}$ & $\begin{array}{c}\text { Meyve } \\
\text { eni (mm) }\end{array}$ & $\begin{array}{c}\text { Meyve } \\
\text { boyu } \\
(\mathrm{mm})\end{array}$ & $\begin{array}{c}\text { Meyve } \\
\text { yüksekliği } \\
(\mathrm{mm})\end{array}$ \\
\hline \multirow[t]{3}{*}{ EM.A } & 2018 & $12.85 \mathrm{~A}$ & 5.99 & 46.66 & 1.70 & 33.11 & 34.48 & 41.24 \\
\hline & 2019 & 12.40 & 6.28 & 51.25 & $1.53 \mathrm{~A}$ & 34.09 & 32.48 & $41.02 \mathrm{~A}$ \\
\hline & Ortalama & $12.62 \mathrm{a}$ & 6.14 & 48.96 & 1.62 & $33.60 \mathrm{a}$ & 33.48 & $41.13 \mathrm{a}$ \\
\hline \multirow[t]{3}{*}{ EM.5 } & 2018 & $12.47 \mathrm{AB}$ & 5.83 & 46.73 & 1.68 & 32.84 & 33.98 & 40.99 \\
\hline & 2019 & 12.34 & 5.79 & 46.90 & $1.53 \mathrm{~A}$ & 33.98 & 32.99 & $40.03 \mathrm{AB}$ \\
\hline & Ortalama & $12.41 \mathrm{ab}$ & 5.81 & 46.81 & 1.61 & $33.41 \mathrm{ab}$ & 33.48 & $40.51 \mathrm{ab}$ \\
\hline \multirow[t]{3}{*}{ Kontrol } & 2018 & $11.97 \mathrm{~B}$ & 5.98 & 49.99 & 1.51 & 32.33 & 34.45 & 40.11 \\
\hline & 2019 & 11.09 & 5.54 & 50.13 & $1.83 \mathrm{~B}$ & 33.03 & 32.89 & $39.38 \mathrm{~B}$ \\
\hline & Ortalama & $11.53 \mathrm{~b}$ & 5.76 & 50.06 & 1.67 & $32.68 \mathrm{~b}$ & 33.67 & $39.75 \mathrm{~b}$ \\
\hline
\end{tabular}

Istatistiksel olarak; uygulamalara ait ortalama değerler küçük harf, yıllara ait değerler ise büyük harfler ile gösterilmiştir. 
Çizelge 4. Uygulamaların meyve renk parametrelerine etkisi

\begin{tabular}{|l|l|l|l|l|l|l|}
\hline & & \multicolumn{1}{c|}{$\mathrm{L}^{*}$} & \multicolumn{1}{c|}{$\mathrm{a}^{*}$} & \multicolumn{1}{c|}{$\mathrm{b}^{*}$} & \multicolumn{1}{c|}{$\mathrm{h}^{\circ}$} & \multicolumn{1}{c|}{$\mathrm{C}^{*}$} \\
\hline EM.A & 2018 & 54.07 & 7.97 & 28.51 & 29.61 & 74.40 \\
\hline & 2019 & $50.41 \mathrm{~B}$ & $8.71 \mathrm{~A}$ & 28.99 & 30.27 & $73.28 \mathrm{~B}$ \\
\hline & Ortalama & $\mathbf{5 2 . 2 4}$ & $\mathbf{8 . 3 4} \mathbf{a}$ & $\mathbf{2 8 . 7 5}$ & $\mathbf{2 9 . 9 4}$ & $\mathbf{7 3 . 8 4} \mathbf{b}$ \\
\hline EM.5 & 2018 & 56.07 & 7.39 & 28.79 & 29.73 & 75.61 \\
\hline & 2019 & $48.78 \mathrm{~B}$ & $8.93 \mathrm{~A}$ & 29.35 & 30.68 & $73.09 \mathrm{~B}$ \\
\hline & Ortalama & $\mathbf{5 2 . 4 3}$ & $\mathbf{8 . 1 6} \mathbf{a}$ & $\mathbf{2 9 . 0 7}$ & $\mathbf{3 0 . 2 0}$ & $\mathbf{7 4 . 3 5} \mathbf{b}$ \\
\hline Kontrol & 2018 & 53.91 & 7.32 & 28.99 & 29.92 & 75.87 \\
\hline & 2019 & $55.81 \mathrm{~A}$ & $6.90 \mathrm{~B}$ & 29.84 & 30.63 & $76.97 \mathrm{~A}$ \\
\hline & Ortalama & $\mathbf{5 4 . 8 6}$ & $\mathbf{7 . 1 1} \mathbf{b}$ & $\mathbf{2 9 . 4 1}$ & $\mathbf{3 0 . 2 7}$ & $\mathbf{7 6 . 4 2} \mathbf{a}$ \\
\hline
\end{tabular}

İstatistiksel olarak; uygulamalara ait ortalama değerler küçük harf, yıllara ait değerler ise büyük harfler ile gösterilmiştir.

olup kontrol grubunda daha açık renkli cevizler elde edilmiştir. Denemenin ikinci yılında, a* ve $C^{*}$ değerinde, iki yılın ortalamasına benzer durum gözlenmiştir. Her iki yararlı mikrobiyal gübre uygulaması ile $a^{*}$ değerinde artış, $C^{*}$ değerinde azalış göze çarpmaktadır. Ceviz meyvesinin $L^{*}, a^{*}$ ve $C^{*}$ değerlerindeki bu farkl111klar, miktobiyal gübre uygulamalarının kontrole göre kısmen de olsa meyve rengini koyulaştırdığı-matlaştırdığını göstermektedir. Özellikle mikrobiyal gübre uygulaması yapılan cevizlerde meyve $L^{*}$ ve $C^{*}$ değerlerinin birlikte azalış göstermesi bunu doğrulamaktadır.

Bakteri uygulamaları ile $\mathrm{h}^{\circ}$ 'da değişim olmaması Atılgan vd. (2019)'nın Salihli kirazındaki bulgularına benzerlik göstermektedir. Diğer yandan, Eşme ayva çeşidinde bitki büyümesini teşvik edici rizobakteri uygulamasının meyve renk değerleri üzerine etkisi gözlenmemiştir (Gerçekçioğlu vd. 2018).

'Chandler' ceviz çeşidinde; palmitik, palmitoleik, margarik, heptadedanoik, stearik, oleik, linoleik, linolenik, araşidonik ve gadoleik asit saptanmıştır (Çizelge 5). Linoleik asidin

Çizelge 5. Uygulamalara göre yağ asidi kompozisyonları (\%)

\begin{tabular}{|l|c|c|c|}
\hline Yağ asidi & EM.A & EM.5 & Kontrol \\
\hline Palmatik(C16:0) & $5.83 \mathrm{~b}$ & $6.36 \mathrm{a}$ & $5.75 \mathrm{~b}$ \\
\hline Palmitoleik(C16:1) & $0.06 \mathrm{a}$ & $0.04 \mathrm{~b}$ & $0.05 \mathrm{a}$ \\
\hline Margarik(C17:0) & $0.05 \mathrm{~b}$ & $0.06 \mathrm{a}$ & $0.05 \mathrm{~b}$ \\
\hline Heptadesanoik(C17:1) & 0.05 & 0.05 & 0.06 \\
\hline Stearik (C18:0) & 2.95 & 2.89 & 3.12 \\
\hline Oleik (C18:1) & 13.22 & 12.90 & 12.49 \\
\hline Linoleik (C18:2) & 61.76 & 62.74 & 62.02 \\
\hline Linoleinik (C18:3) & 15.83 & 14.75 & 16.21 \\
\hline Araşidik (C20:0) & 0.05 & 0.04 & 0.05 \\
\hline Gadoleik (C20:1) & 0.20 & 0.17 & 0.20 \\
\hline TDY yağasidi & 8.88 & 9.35 & 8.97 \\
\hline TDM yağasidi & 91.12 & 90.65 & 12.03 \\
\hline TTDM yağasidi & 13.53 & 13.16 & 78.23 \\
\hline TÇDM yağasidi & 77.59 & 77.49 & 0.12 \\
\hline TDY/TÇDM oran1 & 0.11 & 0.12 & \\
\hline
\end{tabular}

TDY: Toplam doymuş yağ asidi, TDM: Toplam doymamış yağ asidi, TTDM: Toplam tekli doymamış yağ asidi, TÇDY: 
baskın asit olduğu gözlenmiştir. Benzer bulgu birçok araştırıcı tarafından da ifade edilmektedir (Şimşek 2016; Ojeda-Amador vd. 2018; Olut ve Kafkas 2018; Cittadini vd. 2020). Aynı çeşit ile Menemen ekolojisinde yürütülen çalışmada, linoleik asit toplam yă asitlerinin \%60.20’ni oluştururken (Bilgin vd. 2018), Demirci ekolojisinde kontrol grubu ağaçlarda bu oran \%62.02 olarak belirlenmiştir. Linoleik asidi linolenik (\%16.21) ve oleik asitler (\%12.49) izlemiştir. Diğer yandan, palmitik, palmitoleik ve margarik asit kompozisyonunda istatistiksel farklılık saptanmıştır. EM.5 uygulaması ile palmitik ve margarik asit oranının yükseldiği buna karşılık, palmitoleik asit oranının düştüğü belirlenmiștir. Uygulamalar ile toplam doymamış yağ asidi ve toplam tekli doymamış yağ asidi miktarı artarken, toplam çoklu doymamış yăg asidinde azalma tespit edilerek yağ kalitesinin arttığı kanaatine varılmıştır. Cevizdeki yağ asidi miktarının genotip ve çevrenin yanı sıra sulama, gübreleme ve hasat gibi kültürel uygulamalara göre de değişim gösterdiği Şimşek (2016) tarafindan ifade edilmektedir.

Ağaç başına en yüksek verim $2.52 \mathrm{~kg}$ ile EM.5 uygulamasından elde edilirken, bunu aynı istatistiksel grupta yer alan EM.A uygulaması $2.27 \mathrm{~kg}$ ile izlemiştir (Şekil 1). Uygulama yapılmayan ağaçlarda ise verimin düşük bulunması (0.78 kg/ağaç) dikkat çekmektedir. Bakterilerin, birçok meyve türünde; toplam verimi arttırdığı üzerine bulgular değişimleri ortaya konmuştur (İpek vd. 2014; Thakur vd. 2015). Acarsoy Bilgin vd. (2018)'de yaptıkları çalışmada, aynı ceviz çeşidinde Pseudomonas fluorescens bakteri 1rk1 kullanılarak uygulama yapılan ağaçlarda (31.64 ve $27.58 \mathrm{~kg} / \mathrm{ağaç})$ yapılmayanlara göre (21.97 kg/ağaç) verim miktarının daha yüksek olduğunu bildirmişlerdir. Mikrobiyal gübrelerin kullanıldığı diğer bir çalışmada 10 yaşılı Gemlik zeytin çeşidinde verim miktarının yaklaşık iki kat arttığı ifade edilmektedir (Acarsoy Bilgin 2019).

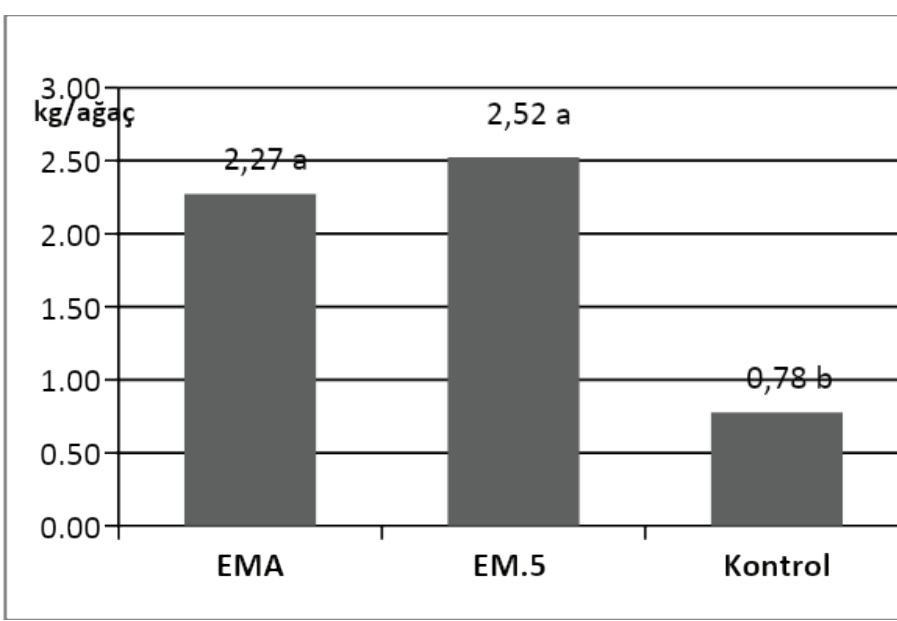

Şekil 1. Uygulamalara göre verim değerleri $(\mathrm{kg} /$ ağaç)

\section{Sonuç}

İnsan ve çevre sağlığı bilincinin yaygınlaşmasıyla, kimyasal girdi kullanımını azaltmaya yönelik uygulamaların geliştirilmesi giderek daha önemli hale gelmektedir. $\mathrm{Bu}$ bağlamda, biyolojik gübre olarak kullanılan yararlı mikroorganizmaların doğrudan ve dolaylı etkileri sayesinde bahçe bitkileri ürünlerinde birçok özellik üzerine olumlu etkileri bulunmaktadır. Demirci ekolojik koşullarında yürütülen bu çalışmada, 'Chandler' ceviz çeşidinde mikrobiyal gübre uygulamalarının meyve ağırlığı, eni, yüksekliği ve bazı renk parametreleri bakımından iyi sonuç verdiği belirlenmiştir. Yağ asidi kompozisyonunun mikrobiyal uygulamalar sonucu iyileştiği 
gözlenmiştir. Önemli bir parametre olan verim değerinde, her iki mikrobiyal gübre uygulaması ile kontrol ağaçlarına kıyasla ciddi bir artış sağlanmıştır. Meyve kalite özellikleri bakımından EM.A mikrobiyal gübre uygulamas1, verim değeri bakımından ise EM.5 uygulaması dikkat çekmektedir. Diğer yandan, meyve kalitesinin birçok faktöre bağlı değişim göstermesi; farklı doz ve uygulama şekli ile çalışmanın genişletilerek sürdürülmesinin faydalı olacağı düşünülmektedir.

\section{Teşekkür}

Araştırılmanın yürütülmesine olanak sağlayan Sayın Kerem Kıncı, EM Agriton doğal ürünler Genel Müdürü Sayın Alper Akman ve Sayın Kevser Türe'ye teșekkür ederiz.

\section{Kaynaklar}

Acarsoy Bilgin, N., Şen, F., Yağmur, B., Özaktan, H., Akbaba, M. 2018. The First Findings to Fruit Characteristics of Nutrient and PGPR Applications on Chandler Walnut Variety. 2nd International Conference on Agriculture, Forest, Food Sciences and Technologies (ICAFOF) 2-5 April, 2018 Çeşme-İzmir/Turkey. 769-775.

Acarsoy Bilgin, N. 2019. Yapraktan Gübre Uygulamalarının Gemlik Zeytin Çeşidinde Verim ve Kalite Üzerine Etkileri. Internatıonal Agean Symposium On Innovative Interdisciplinary Scientific Researches. 449- 453.

Atılgan, H., Misırlı, A., Özaktan, H., Şen, F., Acarsoy Bilgin, N. 2019. Bakteri ve Kompost Çayı Uygulamalarının Salihli Kiraz Çeşidinde Meyve Özellikleri, Verim ve Besin Elementi İçeriklerine Etkileri. Ege Üniv. Ziraat Fak. Derg. 2019, 56 (4): 409-416.

Bilgin, S., Şen F., Özeker E. Acarsoy Bilgin, N. 2018. Bazı Ceviz Çeşitlerinin Menemen Ekolojisinde Morfolojik ve Pomolojik Özelliklerinin Belirlenmesi. ÇOMÜ Zir. Fak. Derg. 6 (1): 31-39

Bona, E., Lingua, G., Todeschini, V. 2016. Effect of bioinoculants on the quality of crops In Bioformulations: For Sustainable Agriculture. Arora N.K., editor; Mehnaz S., editor; and Balestrini R., editor. (eds). New Delhi: Springer India, Private Ltd., pp. 93-124.

Cittadini, M.C., Martín, D., Gallo, S., Fuente, G., Bodoira, R., · Martínez, M., Maestri, D. 2020. Evaluation of hazelnut and walnut oil chemical traits from conventional cultivars and native genetic resources in a non-traditional crop environment from Argentina. European Food Research and Technology. 246:833-843 https://doi. org/10.1007/s00217-020-03453-8

Dede, A. 2013. Bitki Büyüme Düzenleyici Bakterilerin Karakterizasyonu. Anadolu Üniversitesi, Biyoloji Anabilim Dalı, Yüksek Lisans Tezi.

Ertürk, Y., Ercişli, S., Çakmakcı, R. 2012. Yield and growth response of strawberry to plant growth promoting rhizobacteria inoculation. Journal of Plant Nutrition, 35(6): 817-826.

Eşitken, A., Yıldız, H.E., Ercişli, S., Dönmez, M.F., Turan, M., Güneş, A. 2010. Effects of plant growth promoting bacteria (PGPB) on yield, growth and nutrient contents of 
organically grown starwberry. Scientia Horticulturae, 124: 62-66.

Forde, H.I. 1975. Walnuts. In: Editors Janickand J, Moore JN. Advances in Fruit Breeding. 439-455.

Gerçekçioğlu, R., Ertürk, A., Öz Atasever, Ö. 2018. Bitki Büyümesini Teşvik Edici Rizobakteri (PGPR) Uygulamasının Eşme Ayva Çeşidinde (Cydonia vulgaris L.) Verim ve Meyve Özellikleri Üzerine Etkileri. Gaziosmanpaşa Üniversitesi Ziraat Fakültesi Dergisi. 35 (3), 209-216. Güneş, A., Karagöz, K., Turan, M., Kotan, R., Yıldırım, E., Çakmakcı, R., Şahin, F. 2015. Fertilizer efficiency of some plant growth promoting rhizobacteria for plant growth. Research Journal of Soil Biology, 7: 28-45.

Higa, T., Parr. J.F. 1994. Beneficial Effective Microorganisms for a Sustainable Agriculture Environment. International Nature Farming Research Center Atami, Japan. 25s.

İpek, M., Pırlak, L., Eşitken, A., Dönmez, M.F., Turan, M,. Şahin, F. 2014. Plant growthpromoting rhizobacteria (PGPR) increase yield, growth and nutrition of strawberry under high calcareous soil conditions. Journal of Plant Nutrition, 37:990- 1001.

Karlıdağ, H., Yıldırım, E., Turan, M., Pehluvan, M. 2013. Plant growth-promoting rhizobacteria mitigate deleterious effects of salt stress on strawberry plants (Fragaria X ananassa). Hort. Science, 48(5): 563-567.

Liu, F.C., Xing, S.J., Ma, H.L., Du, Z.Y., Ma, B.Y. 2014. Effects of inoculating plant growth- promoting rhizobacteria on the biological characteristics of walnut (Juglans regia) rhizosphere soil under drought condition. The journal applied ecology. 25(5):147582.

Mcguire, R.G. 1992. Reporting of Objective Color Measurements. Hortscience 27:1254-1255.

Mertoğlu, K., Evrenosoğlu, Y. 2017. Ateş Yanıklığı (Erwinia amylovora) Hastalığına Dayanıklılık Islahında, Hastalığa Karşı Testlenmiş F1 Melez Armut Popülasyonunun Fenolojik ve Meyve Özellikleri. Tekirdağ Ziraat Fakültesi Dergisi. 14 (03): 104-115.

Mertoğlu, K., Ileri, O., Altay, Y. 2018. Aqueous leaf extracts effect of some apple cultivars on growth characteristics of the green manure legumes via allelopathy. Fresenius environmental bulletin, 27(6): 4052-4060.

Mordoğan, N., Ceylan, Ş., Delibacak, S., Çakıcı, H., Günen, E., Pekcan, T., Çolak, B. 2013. Organik gübrelemenin zeytin yetiştirilen kumlu-tınlı topraktaki besin element içeriğine etkisi. Adnan Menderes Üniversitesi Ziraat Fakültesi Dergisi. 10(1): $7-13$.

Olut, M.B., Kafkas, E. 2018. Chandler' X 'Kaplan-86' F1 Ceviz Populasyonunun Meyvelerinde Yağ Asidi ve Tokoferol İçeriklerinin Karakterizasyonu. Ç.Ü Fen ve Mühendislik Bilimleri Dergisi Y11 2018 Cilt: 36(8): 53-66.

Ojeda-Amador, R.M., Desamparados Salvador, M., Gómez-Alonso, S., Fregapane, G. 2018. Characterization of virgin walnut oils and their residual cakes produced 
from different varieties. Food Research International. 108: 396-404. doi. org/10.1016/j.foodres.2018.03.066

Özçağıran, R., Ünal, A., Özeker, E., İsfendiyaroğlu, M., 2014. Ilıman İklim Meyve Türleri, Sert Kabuklu Meyveler Cilt III, Ege Üniversitesi Ziraat Fakültesi Yayınlar1, No:566.

Parewa, H.P., Yadav, J., Rakshit, A., Meena, V.S., Karthikeyan, N. 2014. Plant growth promoting rhizobacteria enhance growth and nutrient uptake of crops. Agric Sustain Dev., 2(2):101-116.

Ramos, D.E. 1998. Walnut Production Manual. University of California. Division of Agriculture and Natural Resources. Publication 3373. 319p

Rostamikia, Y., Tabari, M., Asgharzadeh, A., Rahmani, A. 2016. Effect of Plant Growth Promoting Rhizobacteria (PGPR) and Cold Stratification on Seed Germination and Early Growth of Corylus avellana L. Austrian Journal of Forest Science. 4: 337-352.

Ruzzi, M., Aroca, R. 2015. Plant growthpromoting rhizobacteria act as biostimulants in horticulture. Scientia Horticulturae, 196:124-134.

Shakeel, S., Hassan, D.G. 2018. In vitro Bioefficacy of Rhizobacteria, Isolated from Walnut (Juglans regia L.) Rhizosphere in North-Western Himalayas, against Five Fungal Phytopathogens. Applied Biological Research. 20(3):234-243. doi:10.5958/09744517.2018.00032.0
Bahçelerinin Beslenme Durumlarının Yaprak Analizleriyle Belirlenmesi. Yüksek Lisans Tezi Toprak Bilimi ve Bitki Besleme Anabilim Dali.

Şen, S.M. 1980. Kuzeydoğu Anadolu ve Doğu Karadeniz Bölgesi cevizlerinin (Juglans regia L.) seleksiyon yoluyla 1slahı üzerinde araştırmalar, Atatürk Üniversitesi, Ziraat Fakültesi, Bahçe Bitkileri Bölümü (Doktora Tezi), Erzurum.

Şen, S.M. 2017. Cevizin Besin Değeri ve Sağlıklı Beslenmedeki Önemi. Bahçe 46 (Özel Say1 2): 1-9.

Şimşek, M. 2016. Chemical, mineral, and fatty acid compositions of various types of walnut (Juglans regia L.) in Turkey. Bulgarian Chemical Communications, 48(1): 66-70.

Thakur, S., Mehta, K., Sekhar, R.S. 2015. Effect of GA3 and plant growth promoting rhizobacter1a (PGPR) on growth, yield and fruit quality of strawberry, Fragarla $\mathrm{X}$ Ananassa Duch Cv Chandler. International Journal of Advanced Research, 3(11):312 $-317$.

Welbaum, G., Sturz, A.V., Dong, Z., Nowak, J. 2004. Fertilizing soil microorganisms to improve productivity of agroecosystems. Crit Rev Plant Sci 23: 175-193.

Zaman, M., Kurepin, L., Cattoa, W., Pharisc, R. 2014. Enhancing crop yield with theuse of $\mathrm{N}$-based fertilizers co-applied with plant hormones or growth regulators. Published on line in Wiley On line Library.

Solmaz, Y. 2014. Tekirdağ İlindeki Ceviz 